\title{
MEMBERIKAN EDUKASI KEPADA PASIEN GUNA MENERAPKAN EVALUASI BUDAYA DI RUMAH SAKIT DALAM MENINGKATKAN KESELAMATAN PASIEN
}

\author{
Kiki Ramadhani
}

Email : Kikiirmdhn@gmail.com

\section{Latar Belakang}

Rumah sakit merupakan sarana pelayanan kesehatan yang dibutuhkan ketika seseorang sakit dan membutuhkan bantuan kesehatan untuk menyelamatkan kondisi klien. Dengan berlalunya waktu dan perkembangan ilmu pengetahuan dan teknologi, rumah sakit tidak hanya menjadi tempat untuk menyelamatkan pasien. Berbagai layanan kesehatan dapat diakses oleh klien yang membutuhkan bantuan kesehatan. Salah satu faktor yang mempengaruhi kepuasan klien di rumah sakit adalah komunikasi. Komunikasi merupakan komponen utama dalam pelayanan Rumah Sakit, dengan mendengarkan keluhan pasien dan menjelaskan prosedur tindakan yang di lakkan merupakan contoh komunikasi yang harus dilakukan selama melakukan pelayanan di rumah sakit . Komunikasi juga proses yang dilakukan oleh petugas dalam menjalin kerjasama yang baik dengan pasien atau dengan tenaga kesehatan lain dalam mengatasi masalah kesehatan pasien. Pentingnya promosi kesehatan di rumah sakit selain karena efektivitas suatu pengobatan,juga dipengaruhi oleh pola pelayanan kesehatan yang ada, sikap dan keterampilan para unit PKRS, juga sangat dipengaruhi oleh lingkungan, sikap, pola hidup pasien, dan keluarga pasien serta tergantung pada tingkat kerja sama yang positif antara personel kesehatan dengan pihak pasien beserta keluarganya. Pembangunan kesehatan diarahkan untuk meningkatan tingkat kesadaran, kemauan dan kemampuan hidup sehat seseorang agar peningkatan derajat kesehatan masyarakat dapat terwujud setinggi-tingginya. Tujuan dari Promosi Kesehatan Rumah Sakit adalah agar terciptanya masyarakat rumah sakit yang mampu menerapkan Perilaku Hidup Bersih dan Sehat (PHBS) melalui perubahan pengetahuan, sikap, dan perilaku pasien Rumah Sakit serta pemeliharaan lingkungan rumah sakit dan dapat memanfaatkan semua pelayanan yang disediakan oleh Rumah Sakit dengan baik (Depkes RI, 2011). Budaya keselamatan pasien merupakan pola terpadu perilaku 
individu dan organisasi dalam memberikan pelayanan yang aman dan bebas dari cedera. Budaya keselamatan adalah output dari individu dan kelompok terhadap nilai -nilai, sikap, kompetensi, dan pola dan kebiasaan yang mencerminkan komitmen dan gaya dan kemampuan organisasi dan manajemen keselamatan kesehatan. Budaya keselamatan pasien merupakan suatu hal yang penting karena membangun budaya keselamatan pasien merupakan suatu cara untuk membangun program keselamatan pasien secara keseluruhan, karena apabila kita lebih fokus pada budaya keselamatan pasien maka akan lebih menghasilkan hasil keselamatan yang lebih apabila dibandingkan hanya menfokuskan pada programnya saja.

\section{Metode}

Metode yang digunakan dengan melakukan analisis data sekunder yaitu dengan mengumpulkan kajian pustaka terhadap beberapa referensi yang mendukung . Referensi-Referensi tersebut meliputi pembahasan yang bertujuan untuk mengetahui penerapan edukasi dan promosi kesehatan yang dilakukan di rumah sakit guna meningkatkan evaluasi budaya dalam keselamatan pasien.

\section{Hasil}

Rumah sakit merupakan salah satu institusi pelayanan kesehatan profesional yang sangat kompleks sehingga sangat memungkinkan terjadi kejadian tidak diinginkan (KTD) yang dapat berakibat pada terjadinya cedera bahkan sampai dengan kematian pasien. Dalam upaya meminimalisir terjadinya kesalahan akibat melaksanakan suatu tindakan atau tindakan yang seharusnya tidak diambil terkait dengan aspek keselamatan pasien dan kualitas rumah sakit, maka sangat diperlukan pentingnya membangun budaya keselamatan pasien. Budaya keselamatan pasien merupakan nilai nilai, sikap, persepsi kompetensi dan perilaku dari individu yang dapat menentukan komitmen dan gaya kemampuan manajemen rumah sakit dalam meminimalkan bahaya mencelakakan karyawan, manajemen pasien, atau anggota masyarakat keluarga. Budaya keselamatan pasien di suatu rumah sakit dapat diketahui dengan melakukan kajian evaluasi yaitu dengan mengetahui seberapa jauh budaya keselamatan pasien di suatu rumah sakit. Menurut Agency of Healthcare Research and Quality (AHRQ) dalam menilai budaya keselamatan pasien di rumah sakit terdapat beberapa aspek dimensi yang perlu diperhatikan yaitu harapan dan tindakan manajer dalam mempromosikan keselamatan pasien, pembelajaran 
berkelanjutan, kerja sama dalam unit, keterbukaan komunikasi, umpan balik terhadap kesalahan, respon tidak menyalahkan, staf yang adekuat.Keselamatan pasien merupakan inti dari mutu pelayanan kesehatan. Untuk mencapainya, diperlukan komitmen yang kuat dari individu maupun tim. Kombinasi dari berbagai elemen di rumah sakit, secara bersama-sama menghasilkan sebuah situasi yang berisiko tinggi. Untuk dapat memahami risiko yangada dalam sebuah proses yang kompleks pada pelayanan medis/ kesehatan, diperlukan informasi tentang berbagai kasus error dan nearmissed yang pernah dan dapat terjadi. Dari situ kita dapat belajar untuk menutup kesenjangan yang ada, mengurangi morbiditas dan mortalitas untuk mencapai mutu pelayanan yang diharapkan (WHO Patient Safety Curiculum, 2011). Upaya keselamatan pasien sangat memerlukan transformasi budaya organisasi secara menyeluruh.Adapun budaya organisasi merupakan suatu kekuatan yang besar dan tetap ada walaupun terjadi berbagai perubahan di dalamnya. Pengkajian budaya organisasi diperlukan untuk dapat melakukan perubahan yang mendorong dalam upaya peningkatan keselamatan pasien. Diperlukan kebijakan, dan pendampingan dari pimpinan rumah sakit untuk mengawal penerapan pendidikan kesehatan pada pasien dan keluarga, serta pengembangan materi penguatan melalui workshop sebagai salah satu kompetensi pemimpin dibagian promosi kesehatan maupun petugas kesehatan lainnya. Pelaksanaan promosi kesehatan rumah sakit (PKRS) juga sangat bermanfaat untuk menambah wawasan bagi pasien dan keluarganya, serta pengunjung yang berada di rumah sakit tentang beragam jenis penyakit serta langkah-langkah yang diperlukan untuk pencegahannya, selain itu promosi kesehatan di rumah sakit merupakan upaya rumah sakit dalam meningkatkan kemampuan pasien, keluarga dan pengunjung rumah sakit agar dapat berperan secara positif dalam usaha penyembuhan dan pencegahan terhadap penyakit sehingga dapat mempercepat proses penyembuhan serta rehabilitasi, meningkatkan kesehatan, mencegah terjadinya penyakit, serta mengembangkan berbagai upaya untuk meningkatan kesehatan masyarakat melalui pembelajaran sesuai dengan sosial dan budaya masing-masing secara mandiri (Depkes RI, 2011).

\section{Pembahasan}

Budaya Keselamatan Pasien Menurut The Health Foudation, 2011, budaya keselamatan berkaitan dengan sejauh mana organisasi memprioritaskan dan 
mendukung peningkatan keselamatan dengan aman. Organisasi dengan budaya keselamatan positif memiliki komunikasi atas dasar saling percaya, persepsi bersama tentang pentingnya keselamatan, keyakinan pada efektivitas langkahlangkah pencegahan, dan dukungan bagi tenaga kerja. Budaya Organisasi Dalam bukunya Organizational Culture and Leadership, Edgar Schein mendefinisikan budaya sebagai satu set dasar asumsi yang mendefinisikan bagi kita apa yang kita perhatikan, apa arti dari berbagai hal, dan bagaimana bereaksi secara emosional terhadap apa yang sedang terjadi, dan tindakan apa yang harus diambil dalam berbagai macam situasi. Definisi Schein menunjukkan bahwa pemimpin yang ingin menerapkan perubahan radikal dari "norma" dalam suatu organisasi perlu untuk mempengaruhi dan akhirnya mengubah budaya sebelum memimpin upaya perubahan organisasi yang sukses (Russell, 2001). Schein menjelaskan bahwa budaya organisasi dapat dianalisis dalam beberapa level yang berbeda, yaitu artefak, nilai-nilai dan keyakinan, serta asumsi dasar. Nilai dan norma berada pada level menengah dari model tingkatan budaya tersebut. Dua lapisan lainnya adalah lapisan paling superfiisal yaitu artefak, sedangkan lapisan yang terdalam adalah asumsi dasar. Pengukuran budaya keselamatan pasien akan mendapatkan gambaran dimensi budaya keselamatan yang menjadi kekuatan dan kelemahan. Tiap-tiap tipe budaya organisasi memiliki strategi mutu masing-masing. Profil budaya organisasi yang berhasil diidentifikasi akan menentukan strategi mutu yang akan digunakan dalam menetapkan langkah-langkah pengembangan keselamatan pasien. Petugas kesehatan memiliki kewajiban memberikan pelayanan kompresif kepada pasien. Pelaksanaan pendidikan pasien dan keluarga perlu didukung oleh organisasi rumah sakit. Faktor-faktor yang mempengaruhi pelaksanaan pendidikan pasien dan keluarga antara lain budaya organisasi, pengetahuan, pemahaman setiap individu ketika berlatih dan dukungan pemimpin serta ketersediaan fasilitas (Edwards et al., 2012). Kedekatan proses mengajar antara pimpinan dan champion promosi kesehatan sebagai cara yang tepat untuk meningkatkan pengetahuan, perilaku dan kepatuhan (Darawad dan Al-Hussami, 2013). terbentuknya unit promosi kesehatan rumah sakit memacu semangat pokja pendidikan pasien dan keluarga dalammeningkatkan keselamatan pasien.Pendidikan pada pasien dan keluarga yang dapat dilakukan antara lain edukasi kelompok, individu dan interdisiplin Profesional Pemberi Asuhan (PPA), Untuk meningkatkan pengetahuan dan kemauan dalam proses promosi kesehatan diperlukan pengaruh peran perawat dan tenaga 
kesehatan sebagai roll model. Kepatuhan dalam melakukan promosi kesehatan dimulai dengan dorongan secara emosional dan motivasi diri untuk melakukan tindakan yang sesuai dengan aturan yang sebelumnya telah mendapatkan pengetahuan. Senada dengan pengembangan Teori Peplau terhadap pelaksanaan supervisi oleh (Lynch et al., 2008; Senn, 2013) diperlukan peran pengajaran Peplau untuk membangun rasa aman, menjalin hubungan percaya dengan metode pengajaran seperti berbagi pengalaman, merasakan perasaan secara verbal. Pendekatan Peplau merupakan proses interpersonal yang melibatkan hubungan personal antar dua atau lebih yang sesuai dengan konsep menolong individu yang memerlukan pelayanan kesehatan. Aplikasi Riset pada Akreditasi SNARS (Manajemen Komunikasi dan Edukasi) Edukasi merupakan suatu bentuk dalam peningkatan pengetahuan, sikap dan perilaku pasien dan keluarga berdasarkan kebutuhan. Kebutuhan akan edukasi yang diberikan merupakan hak pasien dan keluarga untuk nantinya dapat mengambil keputusan yang tepat guna selama proses asuhan melibatkan interaksi antara profesional pemberi asuhan dengan pasien. Oleh karena itu komisi akreditasi rumah sakit mengeluarkan standar penilaian manajemen komunikasi dan edukasi keselamatan pasien. Standar tersebut menjamin akses asesman edukasi, asesmen kebutuhan edukasi hambatan edukasi, mengatasi hambatan, metode edukasi sampai evaluasi pelaksanaan edukasi. Selain itu edukasi pasien dan keluarga meliputi pelayanan pasien dalam penggunaan obat yang aman, penggunaan peralatan medis yang aman, potensi interaksi antara obat dan makanan, nutrisi, manajemen nyeri dan teknik rehabilitasi (Joint Commission International, 2012; Anonim 2013). Tempat Kerja yang Aman, Bersih, dan Sehat yang ada di Rumah Sakit sangat memelihara sarana dan prasarana lingkungan rumah sakit beserta kelengkapannya baik dalam maupun luar gedung sehingga kawasan Rumah Sakit terlihat rapi, bersih, dan nyaman. Rumah Sakit juga perlu menerapkan Kawasan Tanpa Rokok (KTR) dengan adanya larangan merokok yang diletakkan di setiap sudut dinding, selain itu juga terdapat larangan merokok, larangan tidak membuang sampah sembarangan dan juga tersedianya tempat sampah diseluruh sudut rumah sakit. Kondisi dari tempat sampah yang tersedia di dalam gedung Rumah juga harus dalam kondisi yang baik dan berpenutup. Ketersediaan alat pemadam kebakaran (APAR), hydrant harus tersedia pada setiap lantai di rumah sakit. Untuk kondisi bangunan, rumah sakit ini memiliki kondisi lantai, dinding, dan atap yang bersih dan terawat. Selain itu, rumah sakit ini memiliki tingkat 
pencahayaan yang sesuai (tidak terlalu terang dan tidak terlalu gelap).Perawat merupakan petigas kesehatan dengan waktu kerja tertinggi yang memberikan 24 jam pelayanan terus menerus serta harus berkolaborasi dengan tim kesehatan lain dan oleh karena itu hal tersebut dapat menyebabkan atau berisiko terjadinya Insiden Keselamatan Pasie1. Oleh karena itu peran perawat dalam mengimplementasikan asuhan keperawatan dan mewujudkan keselamatan pasien di rumah sakit dapat dirumuskan sebagai berikut, perawat harus mematuhi standar layanan dan SOP yang telah ditetapkan, menerapkan prisip etik dalam meberikan asuhan keperawatan, memberikan pendidikan kepada pasien dan keluarga pasien tentang asuhan keperawatan yang sedang dijalankan, selalu bekerjasama dengan tim kesehatan yang lainnya dalam memberikan asuhan keperawatan, menerapkan komunikasi yang baik terhadap sejawat, pasien dan keluarga, selalu proaktif dan peka dalam setiap menyelesaikan kejadian atau insiden yang berkaitan dengan keselamatan pasien, mendokumentasikan segala bentuk kegiatan yang ada hubungannya dengan asuhan keperawatan yang dilakukan kepada pasein. Pengobatan dan manajemen dari pasien yang tidak dilakukan dengan hati-hati dan tidak berpotensi terjadinya prosedural Insiden Keselamatan Pasien. Insiden Keselamatan Pasien adalah peristiwa dan kondisi yang tidak disengaja yang mengakibatkan atau berpotensi menyebabkan cedera dapat dicegah pada pasien, Insiden Keselamatan Pasien (IKP) yang terdiri dari Kejadian Tidak Diharapkan (KTD), Kejadian Nyaris Cedera (KNC), Kejadian Tidak Cedera (KTC) dan Kondisi Potensial Cedera (KPC). Keselamatan pasien merupakan prioritas utama dan harus segera dilaksanakan di rumah sakit karena dapat menyebabkan cedera langsung kepada pasien.

Teori Reason menyatakan bahwa insiden keselamatan pasien disebabkan oleh dua faktor, kesalahan laten dan kesalahan aktif. Kesalahan laten terkait dengan insiden keselamatan pasien meliputi lingkungan eksternal, manajemen, lingkungan sosial atau organisasi, lingkungan fisik, interaksi antara manusia dan sistem. Budaya keselamatan adalah bagian dari kesalahan laten yang terkait dengan manajemen, sedangkan indikator budaya keselamatan meliputi kerja sama, komunikasi, kepemimpinan, pelaporan dan respon terhadap kesalahan tidak menghukum. Kunci pencegahan cedera dalam pelayanan keperawatan adalah identifikasi risiko. Hal ini sangat tergantung pada budaya kepercayaan, kejujuran, integritas, dan keterbukaan berkomunikasi dalam sistem asuhan keperawatan. Peningkatan budaya 
keselamatan yang meliputi kerja sama, komunikasi, kepemimpinan, pelaporan dan respon tidak menghukum terhadap kesalahandidapatkan hasil dan pembahasan sebagai berikut :

1. Kerjasama Kerjasama merupakan indikator pertama dari budaya keselamatan pasien. Dalam melaksanakan asuhan keperawatan kepada pasien perawat akan selalu membutuhkan bantuan dari perawat maupun tenaga kesehatan yang lainnya. Bentuk kerjasama tidak hanya berupa saling membantu pekerjaan ketika perawat dihadapkan pada tugas yang sangat banyak dan membutuhkan penyelesaian yang sesegera mungkin, namun juga bisa berupa pembagian tugas berdasarkan kelompok kecil atau tim dalam satu unit Keterlibatan banyak profesi selain tenaga perawat dalam melakukan asuhan keperawatan dapat menimbulkan atau berisiko terjadi cidera jika dilakukan tidak dengan komunikasi dan koordinasi yang tepat, hal itu (cidera) dapat dihindari jika perawat selalu menjaga hubungan baik dengan sesama perawat dan petugas kesehatan lainnya, dan menjaga keharmonisan di lingkungan kerja atau suasana hati untuk mencapai pelayanan kesehatan.

2. Komunikasi. Komunikasi sangatlah penting dalam setiap melaksanakan tugas dalam hal ini dalam melaksanakan asuhan keperawatan pada pasien. Komunikasi yang baik dan benar perlu dilakukan untuk mengkoordinasikan asuhan keperawatan yang melibatkan banyak profesi selain profesi perawat. Komunikasi dalam praktek keperawatan merupakan elemen penting bagi perawat. Dalam melaksanakan asuhan keperawatan untuk mendapatkan hasil yang optimal. Perawat memiliki peran yang paling dominan dalam mencegah terjadinya kesalahan dalam pengobatan, termasuk pelaporan insiden, mendidik diri sendiri dan perawat lain tentang penting komunikasi, memberikan rekomendasi untuk perubahan prosedur dan kebijakan serta keterlibatan dalam melakukan identifikasi permasalahan. Kesalahan medis jarang disebabkan oleh faktor kesalahan manusia secara individual, tetapi lebih karena kesalahan pada sistem komunikasi yang menyebabkan terputusnya rantai dalam sistem tersebut. Hal ini menunjukkan pentingnya menjalin komunikasi dengan baik agar informasi yang disampaikan tidak terputus dan mengakibatkan kerugian pada pasien. Sistem dan interaksi manusia mengacu pada sistem dimana dua sistem berinteraksi atau berkomunikasi dalam ruang lingkup sistem tersebut. Informasi tentang keselamatan pasien perlu diketau oleh semua perawat yang memberikan asuhan keperwatan hal tersebut berfungsi untuk mencegah perawat 
melakukan tindakan yang dapat menyebabkan cidera pada pasien. Komunikasi adalah kunci sukses berinteraksi dalam kehidupan berorganisasi. Ketika komuniksai efektif, arus informasi dalam organisasi yang dinamis akan berjalan lancar sehingga mempercepat proses tercapainya tujuan organisasi.

3. Kepemimpinan Pemimpin harus memiliki komitmen yang kuat terhadap keselamatan pasien, sehingga keselamatan pasien menjadi hal yang utama dalam memberikan pelayanan keperawatan. Pemimpin harus mampu menjadi agen perubahan bagi anak buahnya dengan melaksanakan program keselamatan pasien. Pimpinan mendorong dan menjamin implementasi program keselamatan pasien secara terintegrasi

4. Pelaporan Indikator. pelaporan dalam penerapan budaya keselamatan pasien berada dalam kategori cukup. Perawat diharuskan melaporkan kejadian kesalahan yang tidak disengaja dan kondisi yang mengakibatkan atau berpotensi mengakibatkan cedera yang dapat dicegah pada pasien, yang terdiri dari kejadian tidak diharapkan, kejadian nyaris cedera, kejadian tidak cedera dan kejadian potensial cedera. Melaporkan sebuah kejadian atau insiden keselamatan pasien masih jarang dilakukan atau pun bahkan jika ada pelaporan tentang insiden atau kejadian keselamatan pasien belum ada pelaporan secara resmi. Hal ini disebabkan para perawat takut untuk melaporkan insiden yang terjadi pada pasien karena kesalahan yang dilakukannya. Perawat merasa takut akan hukuman dari penyelia atas kesalahan yang telah ia lakukan saat melakukan asuhan keperawatan. Sejatinya pelaporan insiden keselamatan pasien sangat dibutuhkan oleh semua pihak guna perbaikan pelayanan dalam hal ini khususnya asuhan keperawatan. Informasi dari pelaporan insiden keselamatan pasien yang akurat dan jelas dapat membantu identifikasi akar permasalahan bagaimana insiden tersebut bisa terjadi serta identifikasi faktor risiko sehingga insiden yang sama dapat dicegah untuk kemudian hari. Peran dan fungsi perawat yang salah satunya yaitu peran sebagai peneliti8. Informasi yang benar dan jelas yang diperoleh dai sistem pelaporan, asesmen risiko, kajian insiden, dan audit serta analisis, digunakan untuk menentukan solusi .

5. Respon Tidak Menghukum Terhadap Kesalahan Indikator respon tidak menghukum terhadap kesalahan ini menunjukkan bahwa dimasa yang akan datang pelaporan terhadap insiden keselamatan pasien tidak semata-mata hanya berupa 
pelaporan insiden keselamatan, namun pelaporan tersebut hendaknya ditindaklanjuti guna memperbaiki kesalahan dan mencari akar permasalahan, tidak untuk menghukum perawat yang melakukan kesalahan atau berpengaruh terhadap penilainan kinerjanya. Ketika kesalahan dilaporkan, maka cukup melaporkan masalah sendiri dilaporkan menemukan jalan keluar tidak menunjukkan siapa pelaku harus dihukum. Belajar dari insiden keselamatan pasien hanya akan berhasil jika setiap permasalahan tidak dilihat sebagai kesalahan individu tetapi harus diperhatikan dengan pendekatan sistem dan pemahaman faktor manusia. Sebagaimana diatur dalam Peraturan Menteri Kesehatan Republik Indonesia nomer 755/Menkes/Per/IV/2011 tentang pelaksanaan komite medis di rumah sakit bahwa audit medis dilakukan dengan memprioritaskan semua staf untuk menghilangkan blaming (menyalahkan), naming (menyebut atau mencari siapa yang salah), dan shaming (mempermalukan atau mengakui kesalahan)9. Untuk mampu belajar dari kesalahan harus ditekankan pada upaya mencari apa yang salah, mengapa kesalahan tersebut dapat terjadi, dan apa yang bisa dilakukan untuk memperbaiki kesalahan.

\section{Penutup}

Dalam upaya meminimalisir terjadinya kesalahan akibat melaksanakan suatu tindakan atau tindakan yang seharusnya tidak diambil terkait dengan aspek keselamatan pasien dan kualitas rumah sakit, maka sangat diperlukan pentingnya membangun budaya keselamatan pasien. Budaya keselamatan pasien merupakan pola terpadu perilaku individu dan organisasi dalam memberikan pelayanan yang aman dan bebas dari cedera. Budaya keselamatan adalah output dari individu dan kelompok terhadap nilai-nilai, sikap, kompetensi, dan pola dan kebiasaan yang mencerminkan komitmen dan gaya dan kemampuan organisasi dan manajemen keselamatan kesehatan. Budaya keselamatan pasien merupakan suatu hal yang penting karena membangun budaya keselamatan pasien merupakan suatu cara untuk membangun program keselamatan pasien secara keseluruhan, karena apabila kita lebih fokus pada budaya keselamatan pasien maka akan lebih menghasilkan hasil keselamatan yang lebih apabila dibandingkan hanya menfokuskan pada programnya saja. Untuk meningkatkan pengetahuan dan kemauan dalam proses promosi kesehatan diperlukan pengaruh peran perawat dan tenaga kesehatan sebagai roll model. Kepatuhan dalam melakukan promosi kesehatan dimulai dengan 
dorongan secara emosional dan motivasi diri untuk melakukan tindakan yang sesuai dengan aturan yang sebelumnya telah mendapatkan pengetahuan.

\section{Daftar Pustaka}

Budiono Sugeng, Alamsyah Arief, Tri Wahyu S Tri. (2014). Pelaksanaan program manajemen pasien dengan resiko jatuh di rumah sakit. Jurnal Kedokteran Brawijaya.28(1):78-83

Dora U Tio,pawelas A septo, sriatmi ayun .(2017). Gambaran Budaya Keselamatan Pasien Di Rs Roemani Muhammadiyah Semarang. Jurnal kesehatan masyarakat (eJournal). 5(1):118-125

Fitri maiyulia,Hardisman, Ibrarodes.(2019). Hubungan Budaya Organisasi Dengan Kinerja Pegawai RSUD Mukomuko tahun 2017.Jurnal Kesehatan Andalas. 2019; $8(2): 305-314$

Hani N Juniarti , Ahid A Mudayana.(2018). penerapan standar keselamatan pasien di rumah sakit umum daerah provinsi Nusa tenggara barat. Jurnal kesehatan peltekkes Ternate .11(2):93-108

Nurdianna Fitri .(2017). Pelaksanaan Promosi Kesehatan Di Rumah Sakit Universitas Airlangga Surabaya.Jurnal Promkes.5(2): 217 - 231

riviranty Afrisya.(2015). Analisis Budaya Organisasi dan Budaya Keselamatan Pasien Sebagai Langkah Pengembangan Keselamatan Pasien di RSIA Budi Kemuliaan Tahun 2014. Jurnal Administrasi Rumah Sakit.1(3):196-206

Simamora, R. H., \& Fathi, A. (2019). The Influence Of Training Handover Based SBAR Communication For Improving Patients Safety. Indian journal of public health research \& development, 10(9), 1280-1285.

Suhariyanto,Sri H Tutik,Lestari Astuti dkk.(2019). Peningkatan pendidikan pasien dan keluarga dengan penguatan peran interpersonal champion promosi kesehatan dengan pendekatan peplau. Journal of Hospital Accreditation.01(1): 9-12

Tri Y Herawati.(2015).Budaya keselamatan pasien di ruang rawat inap rumah sakit $\mathrm{x}$ kabupaten Jember. Jurnal Ikesma.11(1):52-60. 
Yasmi Yulia, Thabrany Hasbullah.(2018). Faktor - Faktor yang berhubungan dengan budaya keselamatan pasien di rumah sakit karya Bhakti Pratiwi Bogor tahun 2015. Jurnal Administrasi Rumah Sakit.4(2):98-109

Yartika Yeni.(2018). analisis hubungan Sikap perawat dengan budaya keselamatan pasien di ruang rawat inap RSUD Arifin Achmad provinsi riau.jurnal photon.8(2):8185 